\title{
Education Rights Development in Accordance with European Jurisprudence of Strasbourg
}

PhD. Erdi Kuka

Faculty of Law, University of Tirana, Albania

PhD. Saimir Shatku

Faculty FVFR, UST, Tirana- Albania

Msc. ErmalTauzi

Legal Advisor,

Constitutional Court of Albania

Doi: 10.2478/ajis-2018-0008

\section{Abstract}

Every society has its dynamic, economic, political and social development, which is closely related to the education right in the country and the priority given to it by the particular state-owned bodies created in this context. In the modern period, when globalization and technology are stretched out almost in every vital activity, and the society education plays a central role by helping generations about their skills. A society proves emancipation when all its citizens have access in all legislative and law enforcement structures by shareing their contribute to developing and testing skills in order to find new ways and development forms, related to education. The purpose of this paper is to show the education progress in Albania in accordance with European Jurisprudence of Strasburg, which has played a decisive role in protecting this important human right. Through analyzing the concrete cases dealt with by this court, as well as comparing the national legislation provisions with those issues, we will be able to see the results achieved in the education rights field by the Albanian state through the implementation of those provisions. As a conclusion, it should be acknowledged that the final result achieved in this paper, will help us to improve and develop one of the most relevant rights of the individual human being.

Keywords: Education; discrimination; international practice; university; reforms

\section{Introduction}

The right to education constitutes one of the basic priorities of multidimensional states and societies development and for this reason they have established widespread measure mechanisms of population in education programs.

In this paper we will focus on the education right development in Albania, highlighting the main issues it faces, as long as it consists in one of the main rights in European law. It should be accepted that the University education system is one of the most challenging systems in view of determining competency and student evaluation, which contradicts to European law principles enshrined by the Strasbourg Court case law.

Another issue that matters in this paper is the domestic legislation development in view of implementing European education practices and standards by analyzing the advantages and 
disadvantages presented by this legislation. The whole paper has been drafted in full accordance with the Strasbourg Court's practice, and the conclusions will outline how this right operates in Albania.

\subsection{Research methodology}

In order to better identify the violations rights cases deriving from education in our country, we will review one of the most famous cases of the country regarding the violation of this right, which has been submitted to the Strasbourg Court, named "Vejsel Rizvanolli versus the Academic Staff of the Sports University in Albania".

Also, for the very importance that education right presents, the practice of Strasbourg has built a solid basis for dealing with issues in this context by making available some elements that will be considered like abuses. For this reason, we will consider some of the issues addressed by this court, in order to compare them to the education right in Albania.

\subsection{Analysis Result}

By treating the full development of educational rights in Strasbourg Court, we will create a strong practice implementation in our national legislation, based on law and European principles. Obviously, through its policies all the democratic and social states of the modern period are responsible to take all measures to key reforms and educational opportunities for children or young people, thus in creasing the participation level, as well as eliminating all discrimination forms stemming therefrom.

\section{Educational Practice in Albania}

During economic and social transition years in Albania, education has gained an extraordinary significance for its capacities and the opportunities it offers in social excellence and individual selfesteem. It can be stated that higher education in Albania in one of the main development points for each state, because the professional education of young people would then influence the managerial creation and law enforcement units in line with all European policymaking qualities and standards.

In Albania the public opinion is increasingly combined with the importance that its education and development assumes, by trying every day to stabilize and force all the educational right mechanisms. In the recent years, young people have massively tried and applied to attend Universities, realizing in this way its importance to build a professional career.

Based on the best European standards, we have to accept that Albanian system education is not yet in its highest stage, by showing many political fluctuations and effects, which have adversely affected the establishment and consolidation of its independence. There are numerous problems related to discrimination elements presence regarding the way of functioning, transparency, selection and evaluation of human resources. It is crucial to focus on the higher education university way of organizing, because it is the most important link for integration processes undertaken by our country, thus representing the democratic progress development of the society.

One of the main problems encountered in Albanian university management is the fact that academic and managerial units are not separated in their decision-making. The Rector's responsibility and other governing bodies are both related to the academic staffand also financial and managerial side of the system. This has created a lack of efficiency in the institutional management, the institutional financial funds misuse possibility and also in the lack of University development.

\section{The New Education Legislation}

Through education all the societies bring to their citizens knowledge, information, culture and development, which are necessary for their cultural identity preservation and affirmation in the 
international arena. It seems that the same way is being followed by Albania, which through the educational reform initiative has drafted a comprehensive framework of education systematization, thus raising the whole society awareness on its implementation. The Law no.80/2015 "'On Higher Education and Scientific Research in Higher Education Institutions in the Republic of Albania" marks a major turning point in the entire education system for its own rights and obligations under its development and modernization in accordance with the European standards.

If we analyze law, we see that it changes the funding scheme, introducing the funding concept based on performance, upgrading and improving the service offered to young people. The new law makes the public funding more appropriate for the students, by finding them with limited financial possibilities, creating a special scholarship fund for all categories that do not attend studies because of their financial impossibility and also for the students with excellent results. It increases university autonomy by delegating to public universities a number of important decisions, the number of university students admitted, selection criteria, student selection, tuition fees and the number of academic staff.

The law was based on higher education fundamental principles (The Republic of Albania's official notebook, 2015) such as the quality according to the standards of the European Higher Education Area; equal opportunities, non-discrimination and support to vulnerable groups, meritocracy at all levels, and the establishment of internal and external internal control mechanisms to ensure European standards in higher education, to increase accountability to society and public interest. Nowdays, the reform and modernization of the higher education system is one of the Europe key priorities, especially in consolidating the treatment terms of higher education as a service and a public good that contributes to economic growth and the country or region development. In order to maximize the higher education contribution for a sustainable development and inclusive growth, it is necessary to take all these decisions on a step by step basis.

\section{Strasbourg Practice Regarding Education}

The right to education is of special importance for international human rights law. It is envisioned throughout history in the most important international acts such as the Universal Declaration of Human Rights (Universal Declaration of Human Rights, Article no 26), the International Covenant on Economic, Social and Cultural Rights (UN General Assembly, 1966), the European Convention on Human Rights and Convention on the Rights of the Child (General Assembly Resolution 44/25, 1989), of which the Albanian legislation was also influenced by drafting the education provisions. The Strasbourg Court's practice has played a key role by identifying problematic cases related to education discrimination, thus manifesting the human rights protection and emphasis in full compliance with ECHR (Council of Europe, 1950).

In this framework, we can mention a different number of cases regarding the key issues, in order to be introduced to the human rights violation. Among these issues we can mention, "Vejsel Rizvanolli's case versus the Academic Staff of the Sports University in Albania", which we will consider below.

The protection against discrimination for the access to education was initially developed in the free movement of persons context under Regulation 1612/68, Article 12, addressed specifically to emigrant workers children. In "Kazagrande against Munich City" (European Court Reports (ECJ), 1974) case the applicant was the daughter of an Italian citizen working in Germany. German authorities paid a monthly grant for school children with the purpose of facilitating "educational attendance". The Justice Court ruled that every general measure aimed at facilitating the education pursuit was included within the scope of education.

Refering to Protocol No.1 and the ECHR, Article 2, we can distinguish an independent right of education, which consider discrimination complaints in the education context included within the scope of Article 14. Discrimination because of education, according to the ECHR, has been also discussed in the case of "D.H. and Others v. the Czech Republic"in Chapter 2, section 4.1, and in the case of "Oršuš and Others v. Croatia" (Oršuš and Others v. Croatia) (European Court of Human Rights (ECtHR), 2010) in Chapter 5, Section 3.

If we analyze one of the most famous education right issues like " $\mathrm{DH}$ and others against the 
Czech Republic" (European Court of Human Rights (ECtHR), 2007) we can see that the government argued that the "special" school system was set up to better assist Roma children education, language and correcting the lack of pre-school education. However, the court found that it did not matter if the policy concerned Roma children. In order to prove discrimination, it was necessary to show that they were disproportionately and negatively affected by comparison with the majority of the population, that there was no discrimination purpose. The assignment of Roma children on determination of "special" schools was carried out using intelligence tests.

Despite the fact that this seems like an "unbiased" practice, the nature of testing made it more difficult for Roma children to achieve a satisfactory result and to enter the mainstream education system. The court found that this was proven by referring to statistical evidence, showing a fairly high percentage of Roma pupils placed at "special" schools. The data presented by researchers in relation to their particular geographic region suggested that 50 to $56 \%$ of students in these special schools were Roma, while they represented only about $2 \%$ of the total population in education. Data obtained from intergovernmental sources indicated that about 50 to $90 \%$ of Roma children attended special schools throughout the country. The court found that although the data were incorrect, they reported that the number of Roma children affected was "disproportionately high" versus their composition of the population as a whole.

Further, in "Vejsel Rizvanolli vs. Academic Staff of the Sports University in Albania" (Latifi, 2017) famous case we can briefly address the main facts about the education discrimination:

Objections of the Claimant -Vejsel Rizvanolli were:

1. By virtue of the Decision no. 1 dated 13.01.2012, the Senate of the University of Sports of Tirana (hereinafter UST) has ruled: Approval Article by Article of the Regulation "On the elections for the Authority and Governing Bodies in the UST".

2. With regard to the two articles, the Academic Senate has decided to vote in the ratio of 4 pro/5 against:

- Item 7.3: "The winning candidate in the main unit is considered elected as a member of the Academic Senate without being subjected to the election process"

- Item 7.10 "They have the right to run for members in the Authorities of Steering Bodies, persons who attain the retirement age within $2 / 3$ of the term of the mandate. If they are declared winners, their term shall be terminated with the age of retirement".

3. The Claimant -Vejsel Rizvanolli with the Claim before to the Court states, that: Section 7.10 of the Rulesets a discriminatory restriction, due to age, to a category of subjects, including the claimant as a result of his age.

4. The Principle of Equality and Non-Discrimination constitutes a fundamental universal human right, which as such, is recognized and guaranteed by the Constitution of the Republic of Albania - Article 18, as well as the legislation in force - Article 9 of the Labor Code, Article 11 of the Code Administrative Procedures, Articles 1 and 9 of the Law No. 10221 dated 04.02.2010 "On Protection from Discrimination" and the European Convention on Human Rights - Article 14 thereof.

5. This discrimination has infringed on the claimants the fundamental rights legitimated in Articles 17 and 49 of the Constitution.

Meanwhile, the Objections of the claimant, University of Sports of Tirana, were:

1. In assessing the violation of the principle of protection from discrimination, it is clear that there is no moment to violate this principle by the UST Senate.

2. If the right that is allegedly violated, is acquired by voting for four years, and it appears as a limited right in time. Therefore, if a right appears with a deadline, meeting the deadline is an obligation and not a violation of discrimination.

3. The age in the concrete case is the fixed time limit setby law no. 9741 dated 21 May 2007 "On Higher Education", article 3 thereof.

Finding by trial of the case:

1. Approval of Item 7.10 of the Regulation by Decision No. 1 dated 13.01.2012, and subsequently by Decision No. 2, dated 23.01.2012 (Item 5) by the Academic Senate of UST is at variance with the provisions of articles 17 and 18 of the Constitution of the Republic of Albania. 
2. This decision-making is also contrary to Article 14 of the ECHR, as well as Articles 1 and 9 of the Law no.10221/2010 "On the Protection from Discrimination".

3. Decision No. 20 dated 11.07.2006 of the Constitutional Court affirmed: "According to Article 17 of the Constitution, the rights and freedoms of the individual may be limited only by law [...]. The expression 'only by law' has the meaning [...]. This assessment is only at the discretion of the legislator and not to other bodies [...]".

4. The Court concludes that the decision of the Academic Senate of UST for Item 7.10 (also Item.5) is a partly null and void administrative act, because it was also issued in violation of Article $116 / \mathrm{b}$ of the Code of Administrative Procedures, which provides that Administrative acts shall be considered null and void in the meaning of this Code, where the act is issued by an administrative body in exceeding its legal powers.

5. As an administrative act absolutely null and void in the interpretation of the requirements of Article 117 of the Code of Administrative Procedures, this act does not produce any legal consequences [...].

The decision no.10995 dated 14.11.2012 of Tirana District Court:

- Acceptance of the claim - lawsuit.

- Found partly null and void the decision no.1 of 13.01.2012 of the Academic Senate of UST only for Item 7.10 and the Decision No. 2 of 23.01.2012 only for Item 5 and the decision no. 853, dated 09.04.2013 of the Appeal Court of Tirana upheld the civil decision no.10995 dated 14.11.2012, of Tirana District Court.

\section{Conclusions}

The fundamental human rights, including the right to education, constitute a fundamental and importance right in European law, whose protection takes extensive multidimensional dissemination in all democratic countries aimed and adapting them to this full legislation of international law. Due to this context, Albania as a candidate country for its adoption in the EU structures, should take all necessary measures in view of eliminating all forms of education discrimination, and as we have emphasized in this paper, the key to a successful education is undeniably linked to the development of a full and qualitative education right to all of society levels.

The right to education should be developed in parallel to the human personality and its fundamental rights and respect of freedoms. The education denial impairs the ability of people to develop their personality and to participate by affirming their capacities in the social, political and economic aspects of the country. Further, its denial seriously damages a country's democracy, international peace and human security. Only through a developed education system, the objectives of each state can be achieved in the international arena, and not only can prevent conflicts and human rights talks can be held.

The Albanian legal reform undertaken in the higher education should be considered in terms of the most important elements such as the country's social objectives and priorities, economic and cultural development, analysis of strategic policies of skills, professions and profiles needed for social and economic development or labor market in accordance with the European market. This general positive idea that the new law conveys, is also best suited to European higher education developments, such as the EU Agenda for the Modernization of Higher Education, where the undertaken commitments will shape the reformsto be undertaken in the coming years to complete the European Higher Education Area regardingthe Bologna Processprinciples, in order tobuild a bilateral and quality-based university cooperation in all European area.

\section{References}

Council of Europe. COMPASS- "The Manual on the Right to Education for Young People", 2002. Strasbourg; Council of Europe, European Convention for the Protection of Human Rights and Fundamental Freedoms (ECHR), as amended by Protocols Nos. 11 and 14, Article 2 of Additional Protocol no. 11, 4 November 1950, ETS 5, available at: http://www.refworld.org/docid/3ae6b3b04.html [accessed 4 January 2018] Convention on the Rights of the Child, 1989, New York; 
European Convention on Human Rights(ECHR), 1950, Rome;

Education for the $21^{\text {st }}$ Century. [Online] Availablewww.unesco.org;

European Court Reports (ECJ) 1974 -00773, "Casagrande v. LandeshauptstadtMünchen", case no 9/74 [1974] ECR 773, available at: http://eur-lex.europa.eu/legal-content/EN/TXT/?uri=CELEX\%3A61974CJ0009, [accessed 4 January 2018].

European Court of Human Rights (ECtHR), "Oršuš and others v. Croatia” [GC] (No. 15766/03), 16 March 2010, available at:http://cmiskp.echr.coe.int/tkp197/view.asp?action=html\&documentld=864619\&portal=hbkm \&source=externalbydocnumber\&table=F69A27FD8FB86142BF01C1166DEA398649

European Court of Human Rights (ECtHR), "D.H. and others v. the Czech Republic",[GC] (No. 57325/00), 13 November 2007, available at: https://www.crin.org/en/library/legal-database/dh-and-others-v-czechrepublic

International Covenant on Economic, Social and Cultural Rights (ICESCR), 1976, New York;

Law no. 80/2015 "On Higher Education and Scientific Research in Higher Education Institutions in the Republic of Albania", 2015, Tirana;

Law No.69 / 2012 "On pre-university education" as amended, 2012, Tirana;

Law No. 8872, dated 29.03.2002 "On Professional Education and Formation in the Republic of Albania", as amended, 2002, Tirana;

Latifi, J., (2017), "Vejsel Rizvanollivs Academic Senate of the University of Sports of Tirana", 2012, available online at: http://edulaweu.eu/wpcontent/uploads/2017/11/M5C4-Case-on-discrimination-Juliana.pdf, [accessed 4 January 2018].

Ministry of Education, Sports and Youth in Albania, 2016. [Online] Available https://arsimi.gov.al/files/userfiles/reformaalksh/Raport_Final_Ministria_Arsimit.pdf;

Republic of Albania's Constitution, 1998, Tirana;

The Republic of Albania's official notebook, (2015) , no 248, Law No. 80/2015 "On Higher Education and Scientific Research in Higher Education Institutions in the Republic of Albania", Article no 3, pg.1, available at: http://www.qbz.gov.al/botime/fletore_zyrtare/2015/12/248.pdf, [accessed 4 January 2018]

The global human rights education and training centre[Online] Availablewww.hrea.org;

The power of International Education. [Online] Available www.iie.org;

The jurisprudence of the European Court. [Online]Available http://journals.openedition.org/revus/

Universal Declaration of Human Rights (UDHR), 1948, Paris;

United Nations Development Program. [Online] Available www.undp.org;

UN General Assembly, International Covenant on Economic, Social and Cultural Rights, 16 December 1966, United Nations, Treaty Series, Articles no 13 and 14, vol. 993, p. 3, available at: http://www.refworld.org/docid/3ae6b36c0.html [accessed 4 January 2018].

General Assembly resolution 44/25 of 20 November 1989, Convention on the Rights of the Child, Articles no. 28 and 29, Adopted and opened for signature, ratification and accession, available at: http://www.ohchr.org/en/professionalinterest/pages/crc.aspx , [accessed 4 January 2018]. 